\title{
Intersections of Race and Class
}

\section{Coal Miners and Their Communities}

\section{A Review Essay by SHELTON STROMQUIST}

Buxton: Work and Racial Equality in a Coal Mining Community, by Dorothy Schwieder, Joseph Hraba, and Elmer Schwieder. Ames: Iowa State University Press, 1987. vii, 256 pp. Illustrations, notes, bibliography, index. $\$ 24.95$ cloth.

Ronald L. Lewis, Black Coal Miners in America: Race, Class and Community Conflict, 1780-1980. Lexington: University Press of Kentucky, 1987. xv, $239 \mathrm{pp}$. Tables, charts, illustrations, appendix, notes, bibliography, index. $\$ 25.00$ cloth.

These two fine books arrive by different paths at the intersection of the expanding literatures in Afro-American history and labor history. They illustrate in both vivid and subdued hues the interdependence of race and class in American history. And they offer, in the end, strikingly different views of the experience of black coal miners in America.

The community of Buxton has been the subject of considerable attention in lowa's history. A predominantly black, company-owned coal mining town in Monroe County, its history has acquired an almost mythic quality as a utopia of racial harmony. The authors of this new and more comprehensive examination of Buxton's history are at once respectful of its reputation and curious about the qualities that made its development so seemingly unique. They offer a thorough treatment of its development out of an earlier unplanned communityMuchakinock-and a systematic accounting of the changing ethnic and occupational composition of Buxton over its relatively short lifespan from 1900 through 1918. They also describe the successor community of Haydock to which large numbers of Buxton residents moved as the mining industry in lowa entered its twilight in the 1920s.

The heart of the book is the authors' attempt to capture those qualities of life in Buxton that gave it the special character of a utopia for black miners and their families at a time when blacks in the South were suffering the ravages of Jim Crow segregation and in the North found themselves consigned to residential and occupational ghettos 
that foreclosed opportunity. Through some seventy-five interviews with former residents and through the columns of the Iowa State Bystander, a black-owned newspaper in Des Moines that showed exceptional interest in the Buxton experiment, the authors have reconstructed an intimate and detailed picture of work, community, and family life in the town. In the finest local history tradition, Buxton comes to life in all of its particularity as a place inhabited by real individuals. The sense of Buxton as a place is enhanced by a fine selection of photographs appropriately placed to highlight the text.

If Buxton was an oasis of racial harmony, as the authors are convinced it was from their reading of the evidence, how should this anomaly be explained? They address the issue squarely. Their answers reveal both the strengths and the weaknesses of the book and the perspective on the issues of race and class that it offers.

Buxton was, in the authors' view, a product of welfare capitalist experimentation, an effort on the part of the Consolidation Coal Company to create and guide with a benevolent hand a stable and harmonious community that would reduce worker discontent and eliminate the climate of conflict that was seemingly endemic to the industry. During an 1881 strike Consolidation discovered a valuable source of labor among rural Virginia blacks. Long after the strike the company continued to recruit blacks to Muchakinock and later to Buxton, where they were integrated into a more experienced labor force of European immigrants.

The community of Buxton, created when the company moved its operations in 1900, grew and flourished during the uniquely prosperous years of the very early twentieth century, when mine employment was stable and earnings were predictable. Such conditions led one interviewee to recall that "in Buxton, we didn't want for nothing." The evidence does not permit the authors to determine whether such policies were pursued simply because they were "good business" or because the officers of Consolidation were motivated by some higher mission to promote racial equity. As they note, the displacement of black miners by new immigrants in the mid-teens and then the rather abrupt abandonment of the community suggest fundamentally economic motives. Nevertheless, the extent of the company's paternalistic care for the needs of the community and the principled adherence to equity in pay and promotion suggest that something more may have been at work.

By all accounts, the black community in Buxton flourished as few other black communities have. Stable employment and good wages promoted traditional family roles, educational opportunity, an active community cultural life, and individual pride and dignity. An impressive network of small businesses, professional services, and fraternal 
organizations offered further evidence of community stability. Whites and blacks - blacks made up 55 percent of the town's population in 1905-associated amicably if not intimately at work and in the shops and neighborhoods. Racial divisions were present, but they were not a source of tension.

The weaknesses of the book stem fundamentally from the authors' inattention to the issue of class. The question is not whether Buxton was a more racially divided community than the authors suggest, but whether it was more divided along class lines. An account more attuned to class divisions might confirm the image of interracial cooperation that the book presents, but it might also cast a different light on relations within the community, and perhaps the result would be a more complex picture.

Much of the evidence in the book comes from black middle-class sources-interviewees and the Bystander-whose enthusiasm for the community is leavened with racial pride and gratitude to the corporation. This "Washingtonian" perspective, stressing economic selfimprovement and the patronage of white benefactors, was undoubtedly shared by many of Buxton's middle-class blacks. But was it shared by all classes, black and white, in the community?

At various places in the text, elements of an alternative view, one that is less grateful to Consolidation and more critical of black middleclass leadership, surface briefly. The black community in Muchy had its origins in strikebreaking. Was that a source of tension between black and white miners (as Ronald Lewis's book shows that it was nearly everywhere else in the North)? How long did that tension persist? How was Hobe Armstrong's role as a recruiter of strike breakers regarded by the miners? (Armstrong became the wealthiest black entrepreneur in the community, with continuing close ties to the company.) And what about the role of labor unions? Buxton miners, black and white, were organized by the United Mine Workers of America in the year of the community's creation. We learn that the UMWA was continuously organized in the community thereafter, but we see very little about the role of the union in the community and the lives of the miners. This may again be a function of the middle-class bias in the sources.

The authors discuss residential and occupational divisions in the community extensively, but do not adequately explore status differences. The daughter of a Buxton mine superintendent recalled that she had not known any black families, but, she added, "I didn't know any white miners' families either. That meadow seemed to separate us." The authors note that "the metaphor of a meadow conveys a far greater sense of social distance between classes in Buxton than between races or ethnic groups," (183) but the insight is not developed further. More 
critical views of Consolidation policies do appear from time to time in the text: criticisms of its overall control ("you was a slave in a way of speaking"), its company store, and its educational policies (110-11). The displacement of black miners by new immigrants (presumably a company policy) and the abrupt collapse of the community suggest the limits of corporate benevolence. The middle class, not directly dependent on the corporation as employees, may have been less attuned to those limits than the mine workers.

The authors interviewed some miners, but lacking a full list of interviewees with their occupations, we cannot determine how representative the sample is. The authors indicate in the introduction that, to their regret, they interviewed something less than a full cross-section of the population (12).

Nevertheless, Buxton recreates in loving and respectful detail an extraordinary coal-mining community that illuminates by its uniqueness certain aspects of Afro-American history. In so doing it captures both the racial pride and harmony that the community fostered and that its former residents, predominantly from the middle class, fondly remember.

Ronald Lewis's book, Black Coal Miners in America, examines the diverse and complex contradictions of race and class across two centuries of American history. Lewis's canvas is broad. The picture is framed by a regional typology that draws fundamental distinctions between the experience of black coal miners in the South, the North, and central Appalachia. The story begins with slave miners in colonial Virginia and ends with the role of black miners in the struggle for a democratic union in the 1970s.

Lewis examines the interplay of race and class in different regions over time. He argues that in the South the heritage of coercionslavery and convict labor-and the continuing fact of segregation profoundly affected the economic and social position of black miners in the labor force and persistently undermined the possibilities for interracial unionism before the $\mathrm{CIO}$ era. In the North black miners were almost invariably workers imported during strikes. Their presence threatened the job control and the self-defined worker communities of the coal camps. Virulent racist sentiment for the exclusion of imported black miners contended with periodic but often ineffectual efforts to build interracial solidarity. The pattern of race-class relations in central Appalachia (southern West Virginia in particular) diverges from both northern and southern patterns. There, in fields developed later with labor recruited heavily among southern black miners, a rough pattern of social and economic equality emerged. The subregion was not without discrimination and prejudice, but the economic status of black 
miners was more secure and their active role in mine unionism and the mine "wars" of the teens and twenties was more pronounced.

The strength of Lewis's work lies in the rigor of his comparative regional analysis. He examines the experience of black miners with an exacting lens, focusing primarily on the class dimension. At some points the work is simply a history of class warfare in the mine fields. Lewis never loses sight of the important organizational role of the United Mine Workers, nor, to his credit, of its ambivalent and contradictory behavior on the race issue.

In one sense then, Lewis's book overcomes the limitations of the Buxton study. The tensions involving class and race are at the center of his account. Against his broad canvas, the Buxton case seems even more exceptional, the behavior of the Consolidation Coal Company more incredible, and the moment of racial harmony in south central Iowa more utopian. But what Lewis's work lacks, by virtue of its broad sweep and its focus on class conflict and racial division, is the texture and feel of everyday life that Buxton so powerfully conveys. What other moments of racial harmony or at least accommodation lie beneath the surface of class warfare? What social and economic space did black miners, even in the most unfavorable of circumstances, create for themselves and their families? What strategies of survival and accommodation did black and white miners define for themselves? Lewis does not usually linger long enough or examine closely enough the particular structures of everyday life to answer such questions.

There are more paths converging on this intersection than first meet the eye. These books not only travel the roads of race and class; they arrive by distinctive methodological routes that reflect different but related tendencies within the "new social history." For all of its limitations the "community case study" has a power to illuminate historical reality and the particularity of experience that challenges the best of generalizations. And structural analysis-whether Marxist or nothas the capacity to untangle historical processes and explain their dynamics in ways that profoundly deepen our insight. These books in their distinctive ways significantly advance our understanding of Afro-American urban experience and the tensions and the anomalies of race and class that swirl through and about communities of coal miners, black and white. At their intersection some of the largest and most intractable problems in the American past connect.

Editor's note: Buxton: Work and Racial Equality in a Coal Mining Community recently received the 1988 Benjamin Shambaugh Award from the State Historical Society of Iowa as the most important book on Iowa history published in 1987. 
Copyright of Annals of Iowa is the property of State of Iowa, by \& through the State Historical Society of Iowa and its content may not be copied or emailed to multiple sites or posted to a listserv without the copyright holder's express written permission. However, users may print, download, or email articles for individual use. 